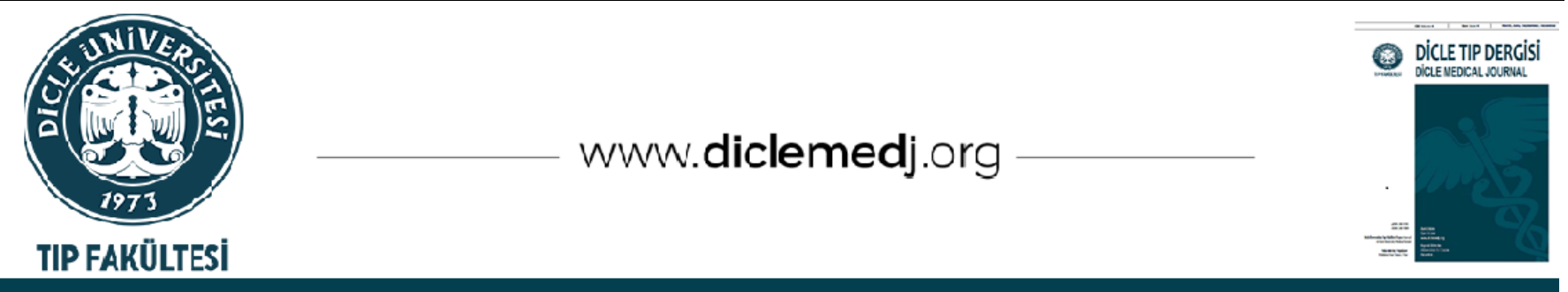

Original Article / Özgün Araştırma

\title{
The Spectrum of $\beta$-Thalassemia Mutations in Batman, South-Eastern Turkey
}

\author{
Sedat Yilmaz ${ }^{1}{ }_{1}$, Murat Çağlayan ${ }^{D_{2}}$ \\ 1 Department of Medical Biochemistry, Medicine Faculty of Adiyaman University, Adiyaman, Turkey \\ 2 Department of Medical Biochemistry, Ministry of Health, Ankara, Turkey \\ Received: 17.04.2020; Revised: 02.11.2020; Accepted: 24.11.2020
}

\begin{abstract}
Objective: In this study, we aimed to determine the mutation types and the frequencies of these mutations in the patients with thalassemia in Batman province and to provide the use of these findings in genetic counselling.

Methods: The study included 46 patients (27 male and 19 female) with a mean age of $9.5 \pm 3.6$ years (range: 3-16 years). In this study, mutations were determined by sequence analysis method.

Results: 7 different mutations were detected in patients. IVS-I-110 (G>A) (56.25\%), codon 44 (-C) del (16.25\%), IVS-I-1 (G>A) (12.5\%), IVS- II-1 (G>A) (6.25\%) were the most common and they were found to constitute $91.25 \%$ of the cases. As in other regions of Turkey, IVI-1-110 (G>A) was the most frequent mutation detected. In this study; 28 mutant alleles including IVS-I-110 (G>A)/IVS-I-1 (G>A) (4), IVS-I-110 (G>A)/IVS-II-1 (G>A) (4), codon 8 (-AA) del/IVS-1-110 (G>A) (1), codon 8 (-AA) del/ codon 44 (-C)del (1), codon 15 (GG-GA)/codon 44 (-C) del (1), codon $44(-\mathrm{C})$ del/IVS-I-1 (G> A) (1), codon 44 (-C) del/ IVS-II-1 (G>A) (1), codon 44 (-C)del/IVS-I-110 (G>A) (1) were found to have formed a compound heterozygous mutation. Among the $\beta$-thalassemia patients in Batman province, $29(56.25 \%)$ were determined to have $\beta^{+}$mutation, and $26(43.75 \%)$ had $\beta^{\circ}$ mutation.

Conclusion: It is important that we, in our study, discovered IVS-II-1 (G>A) mutation compounded with heterozygous in five patients and codon 8 (-AA) del mutation as homozygous in one patient who presented a clinical manifestation of thalassemia intermedia despite having homozygous beta thalassemia. These results will contribute to genetic counseling and prenatal diagnosis.
\end{abstract}

Keywords: Anemia, Hemoglobin Disorders, Mutation, Thalassemia

DOI: $10.5798 /$ dicletip.850314

Correspondence / Yazışma Adresi: Sedat Yilmaz, Department of Medical Biochemistry Medicine Faculty of Adiyaman University Adiyaman Yunus Emre Neighborhood Adiyaman, 02000, Turkey e-mail: drsedatyilmaz@hotmail.com 


\section{Türkiye'nin Güneydoğusunda Batman'da $\beta$-Talasemi Mutasyonlarının Spektrumu}

Öz

Amaç: Bu çalışmada, Batman illinde talasemi hastalarının mutasyon tiplerini ve bu mutasyonların sıklıklarını belirleyerek bu bulguların genetik danışmanlıkta kullanılabilmesini amaçladık.

Yöntemler: Çalışmaya yaş ortalaması $9.5 \pm 3,6$ yıl (dağılım: 3-16 yıl) olan 46 hasta (27 erkek ve 19 kadın) alındı. Bu çalışmada mutasyonlar dizi analizi yöntemi ile saptandı.

Bulgular: Hastalarda 7 farklı mutasyon saptandı. IVS-I-110 (G>A) (\%56,25), codon 44 (-C) del (\%16,25), IVS-I-1 $(\mathrm{G}>\mathrm{A})(\% 12,5)$, IVS-II-1 (G>A) $(\% 6,25)$ en sık olarak belirlendi ve bunların vakaların \%91,25'ini oluşturduğu görüldü. Türkiye'nin diğer bölgelerinde olduğu gibi IVI-1-110 (G>A) en sık saptanan mutasyon oldu. Çalışmada ; IVS-I-110 (G>A)/IVS-I-1 (G>A) (4), IVS-I-110 (G>A)/IVS-II-1 (G>A) (4), codon 8 (-AA)del/IVS-1-110 (G>A) (1), codon 8 (-AA)del/ codon 44 (-C)del (1), codon 15 (GG-GA)/codon 44 (-C)del (1), codon 44 (-C) del/IVS-I-1 (G> A) (1), codon 44 (-C)del/ IVS-II-1 (G>A) (1), codon 44 (-C)del/IVS-I-110 (G>A) (1) adet olmak üzere 28 mutant allelin birleşik heterozigot mutasyon oluşturduğu saptandı. Batman ilinde toplam $\beta$-talasemi hastalarının 29'unda $(\% 56,25) \beta^{+}$mutasyonu, 26'ında $(\% 43,75) \beta^{\circ}$ mutasyonu tespit edildi.

Sonuç: Çalışmamızda Homozigot beta talasemi olmasına rağmen talasemi intermedia klinik tablosu yapan codon 8 (-AA)del mutasyonunu bir hastada IVS-II-1 (G>A) mutasyonunu beş hastada bulmamız önemlidir. Bu sonuçlar genetik danışma ve doğum öncesi tanıda yardımcı olacaktır.

Anahtar kelimeler: Anemi, Hemoglobin Bozuklukları, Mutasyon, Talasemi.

\section{INTRODUCTION}

Thalassemias, characterized by peripheral smear hypochromic microcytic anemia, are an autosomal recessive group of hematological diseases that result from the damaged structure of one or more of the hemoglobin chains $^{1}$. Mutations in $\beta$-globin genes are the main factor in $\beta$-thalassemia ${ }^{2}$. Most often in $\beta$ thalassemia, point mutations, small deletions or insertions into coding regions and exonintron junctions are found. More than 300 different mutations in the-globin gene have been detected across the world ${ }^{3}$. It occurs when mutations that completely inactivate the $\beta$ gene stop $\beta$ globin production. $\beta+$-thalassemia occurs when mutations that partially inactivate the $\beta$ gene reduce $\beta$ globin production. $\beta+$ or $\beta$ ++ ("silent") thalassemias occur depending on the degree of reduction in $\beta$ globin production. The decrease in protein production in the globin causes the accumulation of the $\alpha$-globin chain, creating the pathophysiology of the disease ${ }^{4}$. Patients with a homozygous mutation in the $\beta$-thalassemia gene usually develop a thalassemia major (TM) phenotype. These patients require monthly blood transfusion and treatment of the iron chelating agent desferrioxamine. Some patients with a homozygous mutation in the-thalassemia gene develop a milder thalassemia intermedia (TI) phenotype. These patients survive without blood transfusions or regular blood transfusions ${ }^{5}$. Although they are homozygous beta thalassemia mutations, we can give the FSC8, IVS-II-1, IVS-1-6 mutations ${ }^{6,7}$ as examples of mutations that produce the thalassemia intermedia (TI) phenotype. Excessive iron accumulation in the organs caused by regular transfusion is the main cause of morbidity and mortality in patients with homozygous $\beta$ thalassemia. Therefore, early diagnosis of thalassemia intermedia phenotypes is important, although they are homozygous beta thalassemia mutations, which do not require regular blood transfusion ${ }^{8-13}$. Epidemiological and molecular data should be collected in order to provide appropriate prenatal counseling to 
pregnant women affected by thalassemia. This collected data will contribute to the success of

Turkey's hemoglobinopathy prevention program. Batman is a city which is located in the southeast of Turkey, have a population of approximately 599.103 people. Batman province is located between the eastern meridians of 41 degrees 10 minutes and 41 degrees 40 minutes and the northern parallels of 38 degrees 40 minutes and 37 degrees 50 minutes. In this study, we aimed to determine the mutation types and the frequency of these mutations in 46 patients in Batman province and to make these findings available for genetic counseling.

\section{METHODS}

\section{Area of study and ethical approval}

This study was carried out between January 2013 and December 2014 in Adiyaman University Faculty of Medicine, Department of Medical Biochemistry. The study protocol was approved by the Adıyaman University Training and Research Hospital Ethics Committee and the parents of all patients gave written consent to the study. One of the main clinical criteria recommended for determining patients with thalassemia intermedia is the age of medical consultation. In $\beta$-thalassemia major, clinical findings generally emerge between 6 months- 2 years of age, and in $\beta$-thalassemia intermedia, clinical findings generally emerge after 2 years of age. The level of hemoglobin and hemoglobin composition during the process of consultation plays an important role in the diagnosis of $\beta$ thalassemia intermedia. During the process of consultation, the hemoglobin value is $6-7 \mathrm{~g} / \mathrm{dL}$ in $\beta$-thalassemia major, whereas this value is at the level of $8-10 \mathrm{~g} / \mathrm{dL}$ in $\beta$-thalassemia intermedia. Likewise, during the consultation, $\mathrm{HbA} 2$ value is lower than $4 \%$ in $\beta$-thalassemia major, and higher than $4 \%$ in $\beta$-thalassemia intermedia ${ }^{14}$. The utilization of transfusion is what distinguishes $\beta$-thalassemia intermedia patients clinically from those with $\beta$ -

thalassemia major. Once the transfusion needs of $\beta$-thalassemia intermedia patients is greater than 8 units per year, they are reclassified as $\beta$ thalassemia major ${ }^{15}$. Our study group was comprised of transfusion dependent patients over the age of two. In other words, they are the patients who are currently receiving treatment and are past the stage of consultation. For this reason, the need for transfusion was used as a criterion in the differentiation of patients with beta thalassemia major and beta thalassemia intermedia. Those with a transfusion need of less than 8 units per year were classified as beta thalassemia intermedia, whereas those with a transfusion need of more than 8 units per year were classified as beta thalassemia major.

\section{Detection of beta-globin gene mutation}

\section{Sample collection}

Whole blood samples taken into EDTA tubes taken from the antecubital areas of $\beta$ thalassemia patients were stored at $-20^{\circ} \mathrm{C}$ until the planned number was reached.

\section{DNA Extraction}

By using QIA amp DNA blood mini QIAcube kit (Qiagen, Hilden, Germany CA No. 51104), DNA was extracted from whole blood samples. DNA concentration and purity were determined with the Qubit dsDNA Assay kit (USA) in the Qubit $2.0 \mathrm{fl}$ urometer (Invitrogen by life technologies) device.

\section{Primers}

Primer sets were designed on HBB DNA sequences. (NCBI Reference Sequence: NG000007.3). Primers were synthesized at standard molecular biology quality. (Protech Technology Enterprise Co., Ltd, Taiwan). Primer sets synthesized for the detection of 
HBB gene mutations in exon 1, exon 2 and exon 3 are shown in table 1.

Table I: Primary sets for detection of HBB gene mutations

\begin{tabular}{|c|c|}
\hline $\begin{array}{l}\text { Detection } \\
\text { for }\end{array}$ & Sequence $\left(5^{\prime}\right.$ to $\left.3^{\prime}\right)$ \\
\hline Exon 1 & $\begin{array}{l}\text { P1 5'-GCCAGAAGAGCCAAGGACAGGTACGGC-3' } \\
\text { (forward) }\end{array}$ \\
\hline Exon 2 & $\begin{array}{l}\text { P2 5'-TCCTGAGACTTCCACACTGATGCAATC-3' } \\
\text { (reverse) }\end{array}$ \\
\hline Exon 3 & $\begin{array}{l}\text { P3 5'-TTGCACCATTCTAAAGAATAACAGTGA-3' } \\
\text { (forward) }\end{array}$ \\
\hline Exon 3 & $\begin{array}{l}\text { P4 5'-CAGGGGCTGTTGCCAATGTGCATTAGCTG- } \\
\text { 3' (reverse) }\end{array}$ \\
\hline
\end{tabular}

\section{DNA Amplification}

DNA amplification was performed with GeneAmp PCR System 9700 thermocycler (Applied Biosystems). Polymerase Chain Reaction (PCR) was entered at $93^{\circ} \mathrm{C}$ with 40 denaturation cycles for 150 seconds. The process continued with 36 cycles including denaturation at $93^{\circ} \mathrm{C}$ for 30 seconds, annealing at $58^{\circ} \mathrm{C}$ for 45 seconds and primer extension at $72^{\circ} \mathrm{C}$ for 60 seconds. And it was completed with the last extension step at $5^{\circ} \mathrm{C}$ for 5 minutes.

\section{DNA scanning}

Electrophoresis was performed on PCR products on $2.5 \%$ agarose gel containing ethidium bromide. After the electrophoresis process, the decomposition of PCR products in the gel was determined by giving UV light from the lower part. The movement of DNA in the gel was determined by the traces formed as a result of the movement of dyes such as Xylenecyanol and Bromophenol blue. PCR products were purified with the QIAquick PCR Purification kit (Qiagen Inc.).

\section{DNA sequencing}

DNA sequencing was done in ABI prism 3130 Genetic Analyzer (Applied Biosystems, Foster
City, CA) with BigDye Terminator v3.1 Loop Sequencing kit .

\section{RESULTS}

In total, 46 pediatric patients with $\beta$ thalassemia were investigated for mutation. While 41 of the patients were unrelated, 6 were siblings. Since 12 of the 92 alleles of $46 \beta$ thalassemic patients were found in siblings, they were excluded from the study when calculating their frequency and 80 allele were evaluated. In total, 7 different mutations were detected in 80 allele at different rates. The frequencies of mutations were IVS-I-110 (G>A) (56.25\%), codon 44 (-C) (16.25\%), IVS-I-1 $(\mathrm{G}>\mathrm{A})(12.5 \%), \mathrm{IVS}-\mathrm{II}-1 \mathrm{G}(\mathrm{G}) \mathrm{A})(6.25 \%)$, codon 8 (-AA) (5\%), codon 36/37 (-T) (2.5\%), codon 15 (GG-GA) (1.25\%) (Table II). IVS-I-110 (G>A) $(56.25 \%)$ mutation in $\beta$-thalassemia patients in Batman province was the most common type of mutation seen in patients, as in other geographical regions of Turkey. $\beta$-thalassemia mutations were homozygous in $67.5 \%$ of the patients and compound heterozygous in $32.5 \%$ of the patients. Of the 46 patients with $\beta$ thalassemia who participated in this study, 32 were found to have 5 types of homozygous mutations. The frequency of homozygous mutations were IVS-I-110 (G>A) (45\%), IVS-I-1 $(\mathrm{G}>\mathrm{A})(7.5 \%)$, codon $44(-\mathrm{C})(10 \%)$, codon $36 / 37(-\mathrm{T})(2.5 \%)$, codon 8 (-AA) (2.5\%), (Table III). Eight kinds of heterozygous compound mutations were found in 14 of 46 patients with $\beta$-thalassemia participating in this study; IVS-I-110 (G>A) / IVS-I-1 (G>A) ( $\mathrm{n}=$ 4), IVS-I-110 (G>A) / IVS-II-1 (G>A) ( $n=4)$, codon $8(-A A)$ del /IVS-1-110 (G>A) $(n=1)$, codon $8(-A A)$ del / codon $44(-C)$ del $(n=1)$, codon 15 (GG-GA) / codon $44(-\mathrm{C})$ del $(\mathrm{n}=1)$, codon $44(-\mathrm{C})$ del/ IVS-I-1 $(\mathrm{G}>\mathrm{A})(\mathrm{n}=1)$, codon $44(-\mathrm{C}) \mathrm{del} / \mathrm{IVS}-\mathrm{II}-1(\mathrm{G}>\mathrm{A})(\mathrm{n}=1)$, codon $44(-$ C) del/ IVS-I-110 (G>A) $(n=1)$ (Table IV). Among the $46 \beta$-thalassemia patients who participated in this study, 40 (87\%) had $\beta$ - 
thalassemia major phenotype, and 6 (13\%) had $\beta$-thalassemia intermedia phenotype (Table V).

Table II: Mutations and frequency rates in patients with $\beta$-thalassemia from Batman

\begin{tabular}{|llllc|}
\multicolumn{1}{c}{$\begin{array}{c}\text { Mutation } \\
\text { Name }\end{array}$} & \multicolumn{1}{c}{$\begin{array}{c}\text { Mutation } \\
\text { HGVS Name }\end{array}$} & $\begin{array}{c}\text { Mutati } \\
\text { on } \\
\text { Type }\end{array}$ & $\begin{array}{c}\text { Number of } \\
\text { mutant } \\
\text { alleles }\end{array}$ & $\%$ \\
\hline $\begin{array}{l}\text { IVS-I-110 } \\
\text { (G>A) }\end{array}$ & $\begin{array}{l}\text { HBB:c.93- } \\
\text { 21G>A }\end{array}$ & $\beta^{+}[8]$ & 45 & 56.25 \\
\hline $\begin{array}{l}\text { Codon 44 (-C) } \\
\text { DEL }\end{array}$ & HBB:c.135delC & $\beta^{\circ}[8]$ & 13 & 16.25 \\
\hline $\begin{array}{llll}\text { IVS-I-1 (G>A) } \\
\text { HBB:c.92+1G> }\end{array}$ & $\beta^{\circ}[8]$ & 10 & 12.5 \\
\hline $\begin{array}{l}\text { IVS-II-1 (G>A) } \\
\text { >AB:c.315+1G }\end{array}$ & $\beta^{\circ}[8]$ & 5 & 6.25 \\
\hline $\begin{array}{l}\text { Codon 36/37 } \\
\text { (-T) }\end{array}$ & HBB:c.112delT & $\beta^{\circ}[8]$ & 4 & 5 \\
\hline $\begin{array}{l}\text { Codon 15 (GG- } \\
\text { GA) }\end{array}$ & HBB:c.48G>A & $\beta^{\circ}[8]$ & 2 & 2.5 \\
\hline $\begin{array}{l}\text { Codon 8 (-AA) } \\
\text { DEL }\end{array}$ & $\begin{array}{l}\text { HBB:c.25_26d } \\
\text { elAA }\end{array}$ & $\beta^{\circ}[8]$ & 1 & 1.25 \\
\hline $\begin{array}{l}\text { HGVS: Human } \\
\text { Variation Society }\end{array}$ & Genome & Total & 80 & 100 \\
\hline
\end{tabular}

Table III: Homozygous mutations and frequency rates in patients with $\beta$-thalassemia from Batman

\begin{tabular}{|c|c|c|c|}
\hline $\begin{array}{l}\text { Homozygous } \\
\text { Mutations }\end{array}$ & $\begin{array}{l}\text { Number of } \\
\text { mutant } \\
\text { alleles } \\
\text { together with } \\
\text { brothers } \\
\text { and/or } \\
\text { sisters }\end{array}$ & $\begin{array}{l}\text { Number } \\
\text { mutant } \\
\text { alleles } \\
\text { without } \\
\text { brothers } \\
\text { and/or } \\
\text { sisters }\end{array}$ & $\begin{array}{l}\text { Percentage } \\
\text { in total } \\
\text { alleles }\end{array}$ \\
\hline IVS-I-110 (G>A) & 40 & 36 & 45 \\
\hline IVS-I-1 (G>A) & 8 & 6 & 7,5 \\
\hline $\begin{array}{l}\text { Codon } 44 \quad(-C) \\
\text { del }\end{array}$ & 12 & 8 & 10 \\
\hline $\begin{array}{l}\text { Codon } 36 / 37 \text { (- } \\
\text { T) }\end{array}$ & 2 & 2 & 2.5 \\
\hline $\begin{array}{l}\text { Codon } 8 \text { (-AA) } \\
\text { del }\end{array}$ & 2 & 2 & 2.5 \\
\hline Total & 64 & 54 & 67.5 \\
\hline
\end{tabular}

Table IV: Compound heterozygous mutations and frequency rates in patients with $\beta$-thalassemia from Siirt

\begin{tabular}{|c|c|c|c|c|}
\hline Mutation 1 & Mutation 2 & $\begin{array}{l}\text { Number } \\
\text { of } \\
\text { patients }\end{array}$ & $\begin{array}{l}\text { Number of } \\
\text { mutant } \\
\text { alleles } \\
\text { without } \\
\text { brothers } \\
\text { and/or } \\
\text { sisters }\end{array}$ & $\begin{array}{l}\text { Percentage } \\
\text { in total } \\
\text { alleles }\end{array}$ \\
\hline $\begin{array}{l}\text { IVS-I-110 } \\
(G>A)\end{array}$ & IVS-I-1 (G>A) & 4 & 6 & 7,5 \\
\hline $\begin{array}{l}\text { IVS-I-110 } \\
(\mathrm{G}>\mathrm{A})\end{array}$ & $\begin{array}{l}\text { IVS-II-1 } \\
(\mathrm{G}>\mathrm{A})\end{array}$ & 4 & 8 & 10 \\
\hline $\begin{array}{l}\text { Codon } 8 \text { (- } \\
\text { AA) del }\end{array}$ & $\begin{array}{l}\text { IVS-I-110 } \\
(G>A)\end{array}$ & 1 & 2 & 2.5 \\
\hline $\begin{array}{l}\text { Codon } 8 \text { (- } \\
\text { AA) del }\end{array}$ & $\begin{array}{l}\text { Codon } 44(-C) \\
\text { del }\end{array}$ & 1 & 2 & 2.5 \\
\hline $\begin{array}{ll}\text { Codon } & 15 \\
\text { (GG-GA) }\end{array}$ & $\begin{array}{l}\text { Codon } 44(-C) \\
\text { del }\end{array}$ & 1 & 2 & 2.5 \\
\hline $\begin{array}{l}\text { Codon } 44 \quad \text { (- } \\
\text { C) del }\end{array}$ & IVS-I-1 (G>A) & 1 & 2 & 2.5 \\
\hline $\begin{array}{l}\text { Codon } 44 \quad(- \\
\text { C) del }\end{array}$ & $\begin{array}{l}\text { IVS-II-1 } \\
(G>A)\end{array}$ & 1 & 2 & 2.5 \\
\hline $\begin{array}{l}\text { Codon } 44 \text { (- } \\
\text { C) del }\end{array}$ & $\begin{array}{l}\text { IVS-I-110 } \\
(G>A)\end{array}$ & 1 & 2 & 2.5 \\
\hline & & 14 & 26 & 32.5 \\
\hline
\end{tabular}

Table V: Number and percentage of patients with thalassemia major and thalassemia intermedia

\begin{tabular}{|c|c|c|c|c|}
\hline Mutations & $\begin{array}{l}\text { Number } \\
\text { of } \\
\text { transfus } \\
\text { ions in a } \\
\text { year }\end{array}$ & $\begin{array}{l}\text { Phenot } \\
\text { ype }\end{array}$ & $\begin{array}{l}\text { Numbe } \\
\mathbf{r} \text { of } \\
\text { patient } \\
\mathbf{s}\end{array}$ & $\begin{array}{l}\text { Percentage of } \\
\text { patients }\end{array}$ \\
\hline \multicolumn{5}{|l|}{ Homozygous Mutations } \\
\hline $\begin{array}{l}\text { IVS-I-110 (G>A)/ IVS-I- } \\
110(G>A)\end{array}$ & 12 & $\mathrm{TM}$ & 20 & 43,5 \\
\hline $\begin{array}{l}\begin{array}{l}\text { IVS-I-1 } \\
(G>A)\end{array} \\
(G>A) / \quad \text { IVS-I-1 }\end{array}$ & 12 & $\mathrm{TM}$ & 4 & 8,7 \\
\hline $\begin{array}{l}\text { Codon } 44 \text { (-C) del / } \\
\text { Codon } 44(-C) \text { del }\end{array}$ & 12 & $\mathrm{TM}$ & 6 & 13 \\
\hline $\begin{array}{lrl}\text { Codon } 36 / 37 & (-\mathrm{T}) / \\
\text { Codon } 36 / 37(-\mathrm{T}) & \\
\end{array}$ & 12 & $\mathrm{TM}$ & 1 & 2,2 \\
\hline 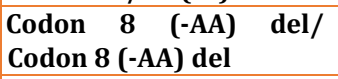 & $<8$ & Tí & 1 & 2,2 \\
\hline \multicolumn{5}{|l|}{ Compound heterozygous } \\
\hline $\begin{array}{l}\text { IVS-I-110 (G>A)/ IVS-I-1 } \\
(G>A)\end{array}$ & 12 & $\mathrm{TM}$ & 4 & 8,7 \\
\hline $\begin{array}{l}\text { IVS-I-110 (G>A)/ IVS-II-1 } \\
(G>A)\end{array}$ & $<8$ & Tİ & 4 & 8,7 \\
\hline $\begin{array}{l}\text { Codon } 8(-A A) \text { del/ IVS-I- } \\
110(G>A)\end{array}$ & 12 & $\mathrm{TM}$ & 1 & 2,2 \\
\hline $\begin{array}{l}\text { Codon } 8 \text { (-AA) del/ } \\
\text { Codon } 44(-C) \text { del }\end{array}$ & 12 & $\mathrm{TM}$ & 1 & 2,2 \\
\hline $\begin{array}{|lll|}\text { Codon } 15 & \text { (GG-GA)/ } \\
\text { Codon } 44(-C) & \text { del }\end{array}$ & 12 & $\mathrm{TM}$ & 1 & 2,2 \\
\hline $\begin{array}{l}\text { Codon } 44(-\mathrm{C}) \text { del/ IVS-I- } \\
1(\mathrm{G}>\mathrm{A})\end{array}$ & 12 & $\mathrm{TM}$ & 1 & 2,2 \\
\hline $\begin{array}{l}\text { Codon } 44(-\mathrm{C}) \text { del/ IVS-II- } \\
1(\mathrm{G}>\mathrm{A})\end{array}$ & $<8$ & Tİ & 1 & 2,2 \\
\hline $\begin{array}{l}\text { Codon } 44(-C) \text { del/ IVS-I- } \\
110(G>A)\end{array}$ & 12 & $\mathrm{TM}$ & 1 & 2,2 \\
\hline
\end{tabular}




\section{DISCUSSION}

In this study that we conducted in Batman, which is a province located in the southwest Anatolian region of Turkey, the frequencies of 5 most common mutations we encountered were determined to be IVS-I-110 (G>A) (56.25\%), codon 44 (C) (16.25\%), IVS- I-1 (G>A) (12.5\%), IVS-II-1 (G>A) (6.25\%), codon 8 (-AA) (5\%) (Table 2). In a study conducted by Çuruk et al. on the prenatal diagnosis of sickle cell anemia and $\beta$-thalassemia in Adana, it was reported that the frequencies of the five most common mutations detected were IVS-I-110 (G> A) (50.6\%), IVS-I-1 (G>A) (\%). 8.1), codon 39 (C> T) $(7.1 \%), \operatorname{FSC} 5$ (-CT) $(6 \%), \operatorname{FSC} 8$ (-AA) $(5.5 \%)^{16}$. Mendilcioglu et al., in their study conducted in Turkey's southwest on the prenatal diagnosis of $\beta$-thalassemia and other hemoglobinopathies, reported the frequencies of the five most mutations that they had detected as IVS-I-110 (G>A) (42.3\%), IVS-II-1 $(\mathrm{G}>\mathrm{A})(8.8 \%)$, IVS-I-6 (T>C) (7\%), IVS-II-745 $(\mathrm{C}>\mathrm{G})(6.8 \%)$, IVS-I-1 (G>A) $(5.1 \%)^{17}$. In our study, which was performed in Batman, a province located in the south-eastern Anatolia region of Turkey, the most frequent mutation we encountered was IVS-I-110 (G>A), and its frequency was similar to the IVS-I-110 (G>A) mutation frequency reported by Çuruk et al. in Adana, and similar to the IVS-I-110 (G>A) mutation frequency reported by Mendilcioglu et al. in southwestern Turkey. In this study we conducted in Batman, the mutation codon 44 (C) $(16.25 \%)$, which we detected as the second most frequent, was not among the five most common mutations found in the study conducted by Çuruk et al. in Adana, nor was it among the five most common mutations found in the study conducted by Mendilcioglu et al. in southwest Turkey. In terms of the finding mutation codon $44(-\mathrm{C})$, which we detected as the second most common in this study, our study differs from the study conducted by Çuruk et al. in Adana, and from the study conducted by Mendilcioglu et al. in southwest Turkey. In this study, the mutation IVS-I-1 (G>A) (12.5\%), which we detected as the third most common, was detected to be the second most common mutation as IVS-I-1 (G>A) $(8.1 \%)$ in the study conducted by Çuruk et al. in Adana, and the fifth most common mutation as IVS-I-1 (G>A) (5.1\%) in the study conducted by Mendilcioglu et al. in southwest Turkey. The frequency of the mutation IVS-I-1 (G>A) that we detected as the third most common in our study is similar to the frequency of the mutation IVS-I-1 (G>A) detected in the study conducted by Çuruk et al. in Adana. However, this differs from the frequency of the mutation IVS-I-1 (G>A), which was found as the fifth most common in the study conducted by Mendilcioglu et al. in southwest Turkey. The mutation IVS-II-1 (G>A) (6,25\%), which we detected as the fourth most common in our study, is not among the five most common mutations found in the study conducted by Çuruk et al. in Adana. However, in the study they conducted in southwest Turkey, Mendilcioglu et al. detected the mutation IVS-II$1(\mathrm{G}>\mathrm{A})(8.8 \%)$ as the second most common mutation. The frequency of the mutation IVS-II$1(\mathrm{G}>\mathrm{A})$, which we detected as the fourth most common in this study, is similar to the frequency of the mutation IVS-II-1 (G>A) that was detected as the second most common in the study conducted by Mendilcioglu et al. in southwest Turkey. However, this differs from the findings of the study conducted by Çuruk et al. in southwest Turkey. The codon 8 (-AA) (5\%) mutation, which presents a clinical manifestation of thalassemia intermedia despite being a homozygous beta thalassemia, was detected as the fifth most common in our study. In their study, Çuruk et al. reported that they found the FSC8 (-AA) (5.5\%) mutation, which presents a clinical manifestation of thalassemia intermedia despite being homozygous beta thalassemia, as the fifth most frequent mutation. Mendilcioglu et al. stated 
that the IVS-II-1 (G>A) (8.8\%) mutation, which presents a clinical manifestation of thalassemia intermedia despite being homozygous beta thalassemia, was found to be the second most common mutation, whereas the IVS-I- $6(\mathrm{~T}>\mathrm{C})$ (7\%) mutation was found to be the third most common mutation. The finding regarding codon 8 (-AA), which we detected as the fifth most common in our study, is similar to the findings of the study conducted by Çuruk et al. in Adana. However, it is different from the findings of the study conducted by Mendilcioglu et al. in southwest Turkey. In this study that we conducted in Batman province, $56.25 \% \beta^{+}$mutation and $43.75 \% \beta^{\circ}$ mutation were detected in the $\beta$-thalassemia patients (Table 2). In their study on prenatal diagnosis of sickle cell anemia and beta-thalassemia in Adana, Çuruk et al. stated that they detected $62,2 \% \beta^{+}$mutation and $34,8 \% \beta^{\circ}$ mutation in $\beta$ thalassemia patients. Mendilcioglu et al. stated that, in the study they conducted for prenatal diagnosis of beta-thalassemia patients in southwest Turkey, they detected $64,6 \% \beta^{+}$ mutation and $35.4 \% \quad \beta^{\circ}$ mutation in $\beta$ thalassemia patients. In this study, which we conducted in Batman province, the fact that we detected more $\beta^{+}$mutation than the $\beta^{\circ}$ mutation in $\beta$-thalassemia patients is similar to the fact that Çuruk et al. detected more $\beta^{+}$ mutation than the $\beta^{\circ}$ mutation in their patients in Adana, and to the fact that Mendilcioglu et al. detected more $\beta^{+}$mutation than the $\beta^{\circ}$ mutation in their patients in southwest Turkey. $40(87 \%)$ of $46 \beta$-thalassemia patients who participated in this study had $\beta$-thalassemia major phenotype, and 6 (13\%) had $\beta$ thalassemia intermedia phenotype (Table V). Turkey Haemoglobinopathy Study Group analyzed a total of 1,988 patient outcomes from 27 thalassemia centers from all over the Turkey, and they stated that 1,658 of the patients $(83.4 \%)$ had $\beta$-thalassemia major phenotype and $215(10.8 \%)$ had thalassemia intermedia phenotype ${ }^{18}$. The elimination of hemoglobinopathies is possible through genetic counseling and through the provision of prenatal diagnosis in all pregnancies under the risk for these disorders ${ }^{19}$. These mutation frequencies we found in $\beta$-thalassemia patients in Batman province will guide the disease processes and complications that may develop in the affected patients. In genetic counseling and in mild cases, even if there are 2 abnormal genes, it will provide data for the decision to continue pregnancy and the management of pregnancies. Hemoglobinopathy Control Program was initiated in 33 provinces in our country in 2003. In 2013, the number of provinces where the Hemoglobinopathy Control Program was implemented increased to 41 . In these 41 provinces, the number of babies born with hemoglobinopathy has decreased from 300 to less than 100 each year. $87 \%$ of soon-to-wed couples were tested for hemoglobinopathy in 2017 in 41 provinces in our county where Hemoglobinopathy Control Program was implemented ${ }^{20-24}$. This study was conducted between the dates of January 2013December 2014, and further studies are required with current data.

Ethics Committee Approval: The study protocol was approved by the Adıyaman University Training and Research Hospital Ethics Committee, dated 20.11.2012 and B.30.2.ADY.02.00.600/42 and the parents of all patients gave written consent to the study.

Declaration of Conflicting Interests: The authors declare that they have no conflict of interest.

Financial Disclosure: This study was supported by the project numbered TIPFBAP $2012 / 003$ by the coordination o scientific research projects of Adiyaman University.

\section{REFERENCES}

1. Clarke GM, Higgins TN. Laboratory Investigation of Hemoglobinopathies and Thalassemias: Review and Update. Clin Chem 2000; 46: 1284-90. 
2. Alwar V, Kavadia R, Singh N, et al. Hunt for hidden trait. J Lab Physicians 2009; 1: 15-18.

3. Fucharoen S, Winichagoon P. Hemoglobinopathies in Southeast Asia: molecular biology and clinical medicine. Hemoglobin 1997; 21: 299-319.

4. Thein SL. Pathophysiology of $\beta$-thalassemia Aguide to molecular therapies. Hematology Am Soc Hematol Educ Program 2005; 31-7.

5. Erlandson ME, Brilliant R, Smith CM. Comparison of sixty-six patients with thalassaemia major and thirteen patients with thalassaemia intermedia. Ann NY Acad Sci 1964; 119: 727-35.

6. Fucharoen S. Genotypes and Phenotypes of Thalassemia: A Discussion. Ann NY Acad Sci 2005; 1054: 518-21.

7. Asadov C, Abdulalimov E, Mammadova T, et al. Genotype-Phenotype Correlations of $\beta$-Thalassemia Mutations in an Azerbaijani Population. Turk J Hematol 2017; 34: 258-263.

8. Davies SC, Wonke B. The management of haemoglobinopathies. Bailliere's Clin Haematol 1991; 4: 361-389.

9. Hershko C. Role of Iron Chelation Therapy in Thalassemia Major. Turk J Haematol 2002; 19: 1216.

10. Sookaromdee P, Wiwanitkit V. Glomerular and Tubular Functions in Transfusion-Dependent. Thalassemia. Turk J Hematol 2018; 35: 137-51.

11. Canatan D, Necati Koç N. The effect of transfusion on pulmonary function tests in patients with thalassemia. Turk J Haematol 2004; 21: 137-9

12. Kervancioğlu M, Devecioğlu C, Okur N. Çocuk kardiyoloji polikliniğine göğüs ağrısı yakınmasıyla başvuran hastaların değerlendirilmesi. Dicle Tıp Dergisi 2005; 32: 196-200.

13. Asadı-pooya AA, Karamıfar H. Body mass index in children with beta-thalassemia major. Turk J Haematol 2004; 21: 177-80
14. Cappellini MD, Cohen A, Eleftheriou A, et al. Guidelines for the Clinical Management of Thalassaemia, 2nd Revised edition. Nicosia (CY): Thalassaemia International Federation, 2008.

15. Rachmilewitz EA, Giardina PJ. How I treat thalassemia. Blood 2011: 118: 3479-88.

16. Çürük MA, Zeren F, Genç $A$, et al. Prenatal diagnosis of sickle cell anemia and beta-thalassemia in southern Turkey. Hemoglobin 2008; 32: 525-30.

17. Mendilcioglu İ, Yakut S, Keser İ, et al. Prenatal diagnosis of $p$-thalassemia and other hemoglobinopathies in southwestern Turkey. Hemoglobin 2011; 35: 47-55.

18. Aydınok Y, Oymak Y, Atabay B, et al. A National Registry of Thalassemia in Turkey: Demographic and Disease Characteristics of Patients, Achievements, and Challenges in Prevention. Turk J Hematol 2018; 35: 12-8.

19. Thein SL. Genetic modifiers of $\beta$-thalassemia. Hematologica 2005; 90: 649-60.

20. Altay C, Başak N. Molecular basis and prenatal diagnoses of hemoglobinopathies in Turkey. Int J Pediatr Hematol Oncol 1995; 2: 283-90.

21. Altay C, Yllgor E, Beksac S, et al. Premarital screening of hemoglobinopathies in Turkey: a pilot study in Turkey. Hum Hered 1996; 46: 112-4.

22. Gürgev A. Beksac S. Gümrük E. Et al. Prenatal diagnosis of hemoglobinopathies in Turkey: Hacettepe experience. Pediatr Hematol Oncol 1996; 13: 163-6.

23. Tüzmen S, Tadmouri GO, Özer A, et al. Prenatal diagnosis of beta-thalassaemia and sickle cell anaemia in Turkey. Prenat Diagn 1996; 16: 252-8.

24. Sağlık Bakanlığı Halk Sağlığı Genel Müdürlüğü Evlilik öncesi hemoglobinopati tarama programı saha rehberi. Çocuk ve Ergen Sağlığı Daire Başkanlığı, 2018. 